\title{
Survei Penelusuran Alumni dan Pengguna Alumni Jurusan Pendidikan Teknik Informatika Undiksha Sebagai Umpan Balik Penyempurnaan Kurikulum Menuju Kurikulum Berbasis Kerangka Kualifikasi Nasional Indonesia
}

\author{
Ni Komang Suni Astini'), Ketut Agustini2), Gede Saindra Santyadiputra3) \\ ${ }^{1}$ Fakultas Teknik dan Kejuruan, Universitas Pendidikan Ganesha (penulis 1) \\ email: astinisuni2@undiksha.ac.id \\ ${ }^{2}$ Fakultas Teknik dan Kejuruan, Universitas Pendidikan Ganesha (penulis 2) \\ email: ketutagustini@undiksha.ac.id \\ ${ }^{3}$ Fakultas Teknik dan Kejuruan, Universitas Pendidikan Ganesha (penulis 3) \\ email: gsaindras@undiksha.ac.id
}

\begin{abstract}
Abstrak
Penelitian ini bertujuan untuk mengetahui bagaimana profil alumni PTI dilihat dari keterserapannya di dunia kerja, keterserapan capaian pembelajaran alumni PTI, dan umpan balik alumni dan pengguna alumni PTI terhadap jurusan PTI.

Penelitian ini merupakan penelitian survei dengan menggunakan metode penelitian deskriptif. Populasi dalam penelitian ini yaitu alumni PTI yang lulus tahun 2013-2015 dan pengguna alumni dengan jumlah sampel 146 alumni PTI dan 73 pengguna alumni. Hasil pengumpulan data menggunakan angket, yang dilakukan dari tanggal 5 April 2016 sampai dengan tanggal 27 Mei 2016. Teknik analisis data yang digunakan analisis deskriptif dengan persentase kemudian dideskripsikan sebagai gambaran profil alumni, keterserapan capaian pembelajaran dan umpan balik alumni dan pengguna alumni.

Hasil penelitian diperoleh 1. Profil alumni PTI jika dilihat dari keterserapannya di dunia kerja sudah baik, ini dapat dilihat dari banyaknya alumni yang sudah bekerja dari 146 responden yang memberikan jawaban yaitu sebanyak $93 \%$ alumni PTI sudah bekerja, masa tunggu alumni PTI untuk mendapatkan pekerjaan tergolong pendek yaitu kurang dari enam bulan, dan pendapatan yang diperoleh alumni PTI dari pertama bekerja sampai saat ini terus meningkat berdasarkan lama bekerja dan kompetensi yang dimiliki. 2. Keterserapan capaian pembelajaran alumni PTI secara umum sudah bagus ini dapat dilihat dari nilai IPK yang diperoleh alumni PTI dari 135 responden yang memberikan jawaban sebanyak $76 \%$ memperoleh nilai IPK antara 3,1 sampai dengan 3,5. Kemudian dalam hal penekanan aspek pembelajaran, kondisi fasilitas belajar mengajar, pengalaman belajar, dan penguasaan kompetensi alumni PTI sudah baik namun masih perlu ditingkatkan lagi. 3. Umpan balik alumni PTI yaitu dikembangkan kurikulum sesuai dengan di SMK dan menyesuaikan kurikulum agar menghasilkan lulusan yang sesuai dengan kebutuhan pasar kerja. Umpan balik dari pegguna alumni PTI yaitu perlunya peningkatan kompetensi terutama dalam penguasaan bahasa Inggris, kepemimpinan dan keterampilan tambahan seperti animasi 2 dimensi, jaringan, dan multimedia khususnya perfileman.
\end{abstract}

Kata kunci: Survei, Metode Deskriptif, Penelusuran Alumni, Profil, Capaian Pembelajaran, Umpan Balik.

\footnotetext{
Abstract

This study aimed at determining the profile of alumnus of PTI seen from the absorptiveness in labor market, the absorptiveness of learning outcomes alumnus of PTI, and the feedback of alumni and alumni users alumnus of PTI toward alumnus of PTI.

This study is in form of survey research by using descriptive research method. The population of this study is the alumnus of PTI who graduated in 2013-2015 and alumni users with the sample of 146 alumnus of PTI and 73 alumni users. The data
} 
was collected by using questionnaire, which was conducted from April $5^{\text {th }}, 2016$ until May $27^{\text {th }}, 2016$. The data analysis used in this study is descriptive analysis by percentage then it is described as the overview profile of the alumni, the absorptiveness of learning outcomes and the feedback of alumni and alumni users.

The results of this study are 1 . The profile alumnus of PTI seen from the absorptiveness in labor market is good, it can be seen from the numbers of alumni who have worked, from 146 respondents who gave answers, 93\% of alumni have been worked, the waiting period alumnus of PTI to get the job is relatively short which is less than six months, and the income derived by alumnus of PTI from the first work until today is increased continuously depends on the length of service and the competencies. 2. The absorptiveness of learning outcomes alumnus of PTI in general is good, it can be seen from the GPA of the alumnus of PTI, from 135 respondents who gave answers, $76 \%$ of alumni obtain GTA from 3.1 to 3.5. Then, in terms of the emphasis of learning aspects, the condition of teaching and learning facilities, learning experiences, and competency mastery of alumnus of PTI are good but it still need to be increased. 3. The feedback alumnus of PTI is the development of the curriculum in accordance with the vocational school and adapts the curriculum to produce graduates who fit the needs of the labor market. The feedback from alumnus of PTI users is the need to increase the competencies especially the mastery of English, leadership and other additional skills such as 2-dimentional animation, networking, and multimedia especially film.

Keywords : Survey, Descriptive Method, Alumni Search, Profile, Learning Outcomes, Feedback.

\section{PENDAHULUAN}

Menurut

peraturan Menteri

Pendidikan dan Kebudayaan Republik Indonesia Nomor 49 Tahun 2014 tentang Standar Nasional Pendidikan Tinggi dinyatakan bahwa, kurikulum adalah seperangkat rencana dan pengaturan mengenai capaian pembelajaran lulusan, bahan kajian, proses, dan penilaian yang digunakan sebagai pedoman penyelenggaraan program studi. Dalam Peraturan Menteri Pendidikan dan Kebudayaan Republik Indonesia Nomor 73 Tahun 2013 tentang Penerapan Kerangka Kualifikasi Nasional Indonesia (KKNI) Bidang Pendidikan Tinggi pada pasal 10 ayat 4 , yakni : setiap program studi wajib menyusun deskripsi capaian pembelajaran minimal mengacu pada $\mathrm{KKNI}$ bidang pendidikan tinggi sesuai dengan jenjangnya. Bahkan pada ayat yang sama juga dinyatakan bahwa : setiap program studi wajib menyusun kurikulum, melaksanakan, dan mengevaluasi pelaksanaan kurikulum yang mengacu pada KKNI bidang pendidikan tinggi. Jelas bahwa semua perguruan tinggi di Indonesia yang menyelenggarakan program studi harus mengembangkan kurikulum dan menyusun Capaian
Pembelajaran dengan menggunakan KKNI sebagai tolak ukur. Menurut Peraturan Presiden Republik Indonesia Nomor 8 Tahun 2012 pada pasal 1 menyatakan bahwa: Kerangka Kualifikasi Nasional Indonesia atau disingkat KKNI merupakan kerangka penjenjangan kualifikasi kompetensi yang dapat menyandingkan, menyetarakan, dan mengintegrasikan antara bidang pendidikan dan bidang pelatihan kerja serta pengalaman kerja dalam rangka pemberian pengakuan kompetensi kerja sesuai dengan struktur pekerjaan di berbagai sektor. Berdasarkan pengertian $\mathrm{KKNI}$ tersebut, tujuan dari kurikulum ini yaitu:

a. Untuk meningkatkan kualifikasi kompetensi antara bidang pendidikan dengan tuntutan dunia kerja yang semakin berkembang.

b. Hal yang paling penting dari Kurikulum Pendidikan Tinggi yang mengacu pada $\mathrm{KKNI}$ adalah capaian pembelajarannya.

Yang termasuk ke dalam capaian pembelajaran yaitu sikap dan tata nilai, kemampuan di bidang kerja, pengetahuan yang dikuasai, kemampuan manajerial. Berdasarkan pernyataan tersebut tentunya Jurusan Pendidikan Teknik Informatika 
harus mengembangkan kurikulum dan menyusun capaian pembelajaran dengan menggunakan KKNI sebagai tolak ukurnya.

Masalah yang muncul adalah kurikulum yang digunakan saat ini masih menggunakan kurikulum 2012 dan belum mengacu pada KKNI. Untuk menyempurnakan kurikulum berbasis $\mathrm{KKNI}$ di Jurusan tidaklah mudah, dibutuhkan pemahaman dan komitmen dosen. Di sini peran dan dukungan ketua Jurusan, dekan dan rektor sangat penting. Salah satu indikator yang sangat penting dalam perbaikan kurikulum yaitu adanya informasi dari alumni dan pengguna alumni terhadap kurikulum tersebut.

Melalui alumni dan pengguna alumni, Jurusan Pendidikan Teknik Informatika bisa mendapatkan informasi guna untuk mengetahui kualifikasi kompetensi antara bidang pendidikan dengan tuntutan dunia kerja yang semakin berkembang. Selain itu adalah untuk mengetahui bagaimana keterserapan capaian pembelajaran alumni dalam dunia kerja. Untuk itu diperlukan umpan balik dari alumni dan pengguna alumni sehingga dapat dijadikan acuan dalam penyempurnaan kurikulum di Jurusan Pendidikan Teknik Informatika. Selama ini Jurusan Pendidikan Teknik Informatika belum memiliki data yang akurat mengenai profil lulusan, Relevansi kurikulum dengan pasar kerja, dan sejauh manakah keterserapan capaian pembelajaran terhadap kurikulum yang di terapkan di Jurusan Pendidikan Teknik Informatika. Untuk mendapatkan informasi tersebut diperlukannya sebuah penelitian mengenai survei penelusuran alumni.

Berdasarkan uraian masalah yang telah dipaparkan di atas penulis melakukan sebuah penelitian dengan judul "Survei Penelusuran Alumni Jurusan Pendidikan Teknik Informatika Undiksha Sebagai Umpan Balik Penyempurnaan Kurikulum Menuju Kurikulum Berbasis KKNI". Dalam penelitian ini peneliti akan terjun langsung kelapangan mencari alumni untuk mendapatkan data alumni yang akurat. Sehingga hasil penelitian survei penelusuran alumni ini dapat dijadikan sebagai masukan atau umpan balik untuk pengembangan jurusan menuju ke arah yang lebih baik. Selain itu dapat juga digunakan sebagai acuan untuk menunjang penyempurnaan kurikulum sehingga mutu lulusan menjadi lebih baik dan dapat terserap pada pasar kerja yang sesuai dengan kemampuan dasar atau bidangnya.

\section{Jurusan Pendidikan Teknik Informatika}

Sejalan dengan perkembangan zaman, menyongsong milenium ke tiga, sebuah era baru dengan tantangan yang lebih berat dan kompleks, Jurusan Pendidikan Teknik Informatika hadir sebagai jawaban atas komitmen Universitas Pendidikan Ganesha untuk turut serta memajukan dan mengembangkan pendidikan teknologi informatika dan komputer di Indonesia pada umumnya, dan Bali pada khususnya. Mulai tahun 1998, Depdiknas telah mengeluarkan kebijakan, di mana Lembaga Pendidikan Tenaga ke pendidikan (LPTK) telah diberikan kewenangan untuk melaksanakan program non ke pendidikan yang dituangkan dalam kebijaksanaan perluasan mandat.

\section{Alumni dan Pengguna Alumni}

Alumni merupakan produk dari suatu institusi pendidikan. Kualitas alumni menunjukkan kualitas dari institusi pendidikan tersebut. Fakta ini semakin terasa khususnya untuk alumni perguruan tinggi. Hal ini karena alumni perguruan tinggi secara langsung akan bersentuhan dengan dunia kerja.

Informasi dari para stakeholder ini sangat penting, terutama untuk melihat sejauh mana masyarakat atau stakeholder memandang Jurusan PTI sebagai pencetak tenaga ahli, terutama di bidang pendidikan dan Teknik Informatika. Repson yang masuk dari para stakeholder dan masyarakat pengguna juga akan bermanfaat bagi Jurusan $\mathrm{PTI}$ sebagai sarana untuk mawas diri agar lebih bisa meningkatkan mutu pendidikan, kualitas layanan, maupun kualitas tenaga ahli yang dicetaknya. 


\section{Tracer study}

Tracer Study bertujuan untuk mengetahui hasil pendidikan dalam bentuk transisi dari dunia pendidikan tinggi ke dunia usaha dan industri, keluaran pendidikan berupa penilaian diri terhadap penguasaan dan pemerolehan kompetensi, proses pendidikan berupa evaluasi proses pembelajaran dan kontribusi pendidikan tinggi terhadap pemerolehan kompetensi serta input pendidikan berupa penggalian lebih lanjut terhadap informasi lulusan.

Tracer Study juga bermanfaat dalam menyediakan informasi penting mengenai hubungan antara pendidikan tinggi dan dunia kerja professional, menilai relevansi pendidikan tinggi, informasi bagi pemangku kepentingan (stakeholders), dan kelengkapan persyaratan bagi akreditasi pendidikan tinggi.

\section{Kurikulum}

Kurikulum pada hakikatnya
merupakan suatu cara untuk
mempersiapkan anak-anak agar
berpartisipasi sebagai anggota yang
produktif dalam masyarakat. Dan tiap
kurikulum, bagaimanapun polanya, selalu
mempunyai komponen-komponen tertentu
yakni pernyataan tentang tujuan dan
sasaran, seleksi dan organisasi bahan dan
isi pelajaran, bentuk dan kegiatan belajar
mengajar, dan akhirnya evaluasi hasil
belajar.

\section{Kerangka Kualifikasi Nasional Indonesia \\ Menurut Peraturan Presiden}

Republik Indonesia Nomor 8 Tahun 2012 pada pasal 1 Kerangka Kualifikasi Nasional Indonesia atau disingkat KKNI merupakan kerangka penjenjangan kualifikasi kompetensi yang dapat menyandingkan, menyetarakan, dan mengintegrasikan antara bidang pendidikan dan bidang pelatihan kerja serta pengalaman kerja dalam rangka pemberian pengakuan kompetensi kerja sesuai dengan struktur pekerjaan di berbagai sektor. Tujuan dari kurikulum KKNI yaitu untuk meningkatkan kualifikasi kompetensi antara bidang pendidikan dengan tuntutan dunia kerja yang semakin berkembang dan menekanan capaan pembelajarannya.

Deskripsi capaian pembelajaran dalam Peraturan Presiden Republik Indonesia No. 8 Tahun 2012 tentang Kerangka Kualifikasi Nasional Indonesia, meliputi sikap dan tata nilai, kemampuan di bidang kerja, pengetahuan yang dikuasai, kemampuan manajerial.

\section{METODE}

Penelitian ini merupakan penelitian survei sedangkan metodenya adalah deskriptif persentase. Penelitian ini bermaksud untuk menguraikan kondisi dan situasi dari alumni Jurusan Pendidikan Teknik Informatika yang lulus tahun 2013-2015 yang terkait dengan profil alumni ditinjau dari keterserapannya di pasar kerja, capaian pembelajaran, dan umpan balik alumni dan pengguna alumni terhadap relevansi kurikulum yang diterapkan di Jurusan Pendidikan Teknik Informatika dengan kebutuhan pasar kerja.

Penelitian ini akan dilaksanakan di seluruh kota/kabupaten se-Provinsi Bali/lokasi ini diambil karena alumni Jurusan Pendidikan Teknik Informatika mayoritas bekerja atau bertempat tinggal di Provinsi Bali. Hanya sedikit sekali alumni Jurusan Pendidikan Teknik Informatika yang ke luar Provinsi Bali. Penelitian ini dilaksanakan pada rentang waktu bulan Desember sampai Juni tahun 2016. Jumlah populasi adalah 229 orang. Jumlah sampel responden yang akan diteliti sebanyak 146 orang responden alumni PTI dan 76 orang responden pengguna alumni PTI.

Teknik pengumpulan data yang digunakan adalah teknik komunikasi tidak langsung melalui suatu alat pengumpul data berupa angket yang disebarkan kepada semua responden. Kuisioner dalam penelitian ini digunakan untuk memperoleh informasi profil alumni jika dilihat dari keterserapannya di dunia kerja, keterserapan capaian pembelajaran dan umpan balik dari alumni dan pengguna alumni terhadap Jurusan PTI. Kuesioner yang digunakan yaitu kuesioner yang sudah ada dan dimodifikasi dari DIKTI. 
Data yang terkumpul dianalisis secara kualitatif dan kuantitatif. Analisis kualitatif dalam penelitian ini bertujuan untuk mendeskripsikan profil alumni dilihat dari keterserapannya dalam pasar kerja, untuk mendeskripsikan keterserapan capaian pembelajaran terhadap kurikulum di Jurusan Pendidikan Teknik Informatika dan mendeskripsikan umpan balik alumni dan pengguna alumni terhadap relevansi kurikulum terhadap kebutuhan pasar kerja. Sedangkan analisis kuantitatif di sini bertujuan untuk memperoleh presentase dari hasil kuesioner yang nantinya akan dianalisis secara deskriptif.

\section{HASIL DAN PEMBAHASAN}

Dari hasil penelitian yang dilakukan, didapatkan bahwa sebagian besar alumni dan pengguna PTI berasal dari provinsi Bali, hanya sebagian kecil yang tinggal di luar provinsi Bali. Sehingga untuk pengambilan datanya bisa dilakukan secara langsung bertemu dengan alumninya. Dalam pengambilan data peneliti langsung terjun kelapangan mencari alumni dan pengguna alumni. Namun untuk alumni yang tidak memungkinkan peneliti temui secara langsung, peneliti menggunakan beberapa alternatif lain yang digunakan peneliti yaitu dengan memanfaatkan sosial media, seperti e-mail, line, BBM dan facebook.

Dari data yang didapatkan responden yang berjenis kelamin laki-laki lebih banyak dari pada responden yang berjenis kelamin perempuan. Di mana $58 \%$ terdiri dari responden laki-laki dan $43 \%$ terdiri dari responden perempuan. Hasil persentase jumlah alumni laki-laki dan alumni perempuan. Dari data yang diperoleh kebanyakan alumni yang belum menikah. Untuk responden pengguna alumni kebanyakan bergerak dalam bidang pendidikan, industri, jasa, perdagangan, pertanian, kebudayaan dan pariwisata.

\section{a. Profil Alumni PTI dilihat dari keterserapannya dalam dunia kerja}

Keterserapan alumni PTI dalam dunia kerja dapat dilihat dari masa tunggu, bidang pekerjaan yang di tekuni, gaji pertama dan gaji sekarang. Keterserapan alumni dalam dunia kerja sudah baik ini dapat dilihat berdasarkan banyaknya alumni yang sudah bekerja yaitu sebanyak 93\%. Adapun bidang pekerjaan yang ditekuni alumni PTI yaitu BUMN, Swasta, Pemerintah dan BUMN. Untuk hasil persentasenya dapat dilihat pada Gambar 1.

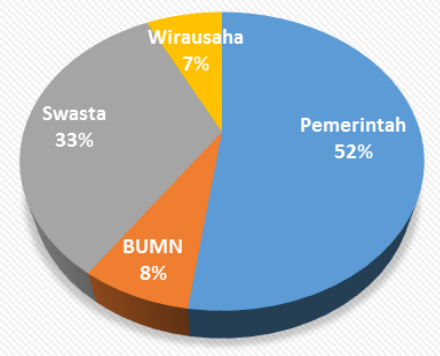

Gambar 1. Bidang pekerjaan alumni PTI

Jika dilihat dari kesesuaian bidang pekerjaan alumni terhadap profil Jurusan PTI, Masa tunggu alumni dalam mencari pekerjaan alumni PTI tergolong pendek yaitu kurang dari enam bulan. Untuk hasil persentasenya dapat dilihat pada Gambar 2.

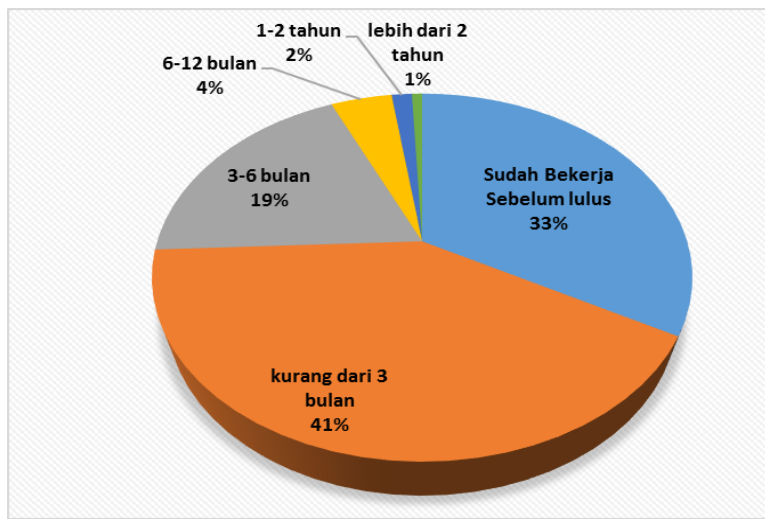

Gambar 2. Masa tunggu alumni PTI dalam mendapatkan pekerjaan

Berdasarkan 140 pernyataan alumni ternyata untuk mendapatkan pekerjaan alumni kebanyakan mendapat informasi pekerjaan tersebut dari temannya. Ini dapat dilihat pada hasil data yang didapatkan dari responden yaitu dari teman $41 \%$, keluarga $22 \%$, mencari sendiri $20 \%$, pengguna kerja $4 \%$, iklan 4 $\%$ dan 9\% informasi lainnya. Untuk melihat hasil persentase sumber informasi 
untuk mendapatkan pekerjaan dapat dilihat pada Gambar 3.

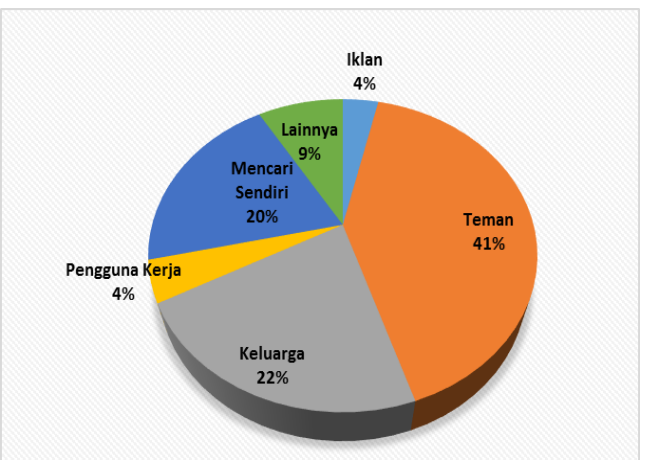

Gambar 3. Sumber informasi untuk mendapatkan pekerjaan

Cara mendapatkan pekerjaan untuk alumni sebagin besar dengan cara berkompetensi dan rekomendasi. Untuk melihat hasil persentase cara alumni mendapatkan pekerjaan dapat di lihat pada Gambar 4.

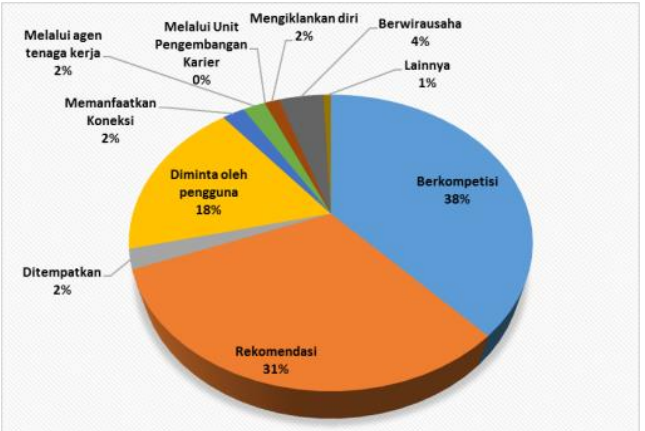

Gambar 4. Cara alumni PTI untuk mendapatkan pekerjaan

Pendapatan alumni dari pertama bekerja sampai sekarang sudah terus meningkat, untuk hasil persentasenya dapat dilihat pada Gambar 5 dan Gambar 6.

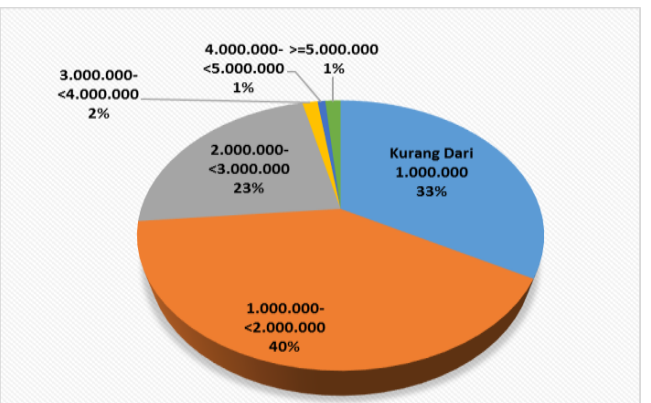

Gambar 5. Pendapatan alumni pada saat pertama bekerja

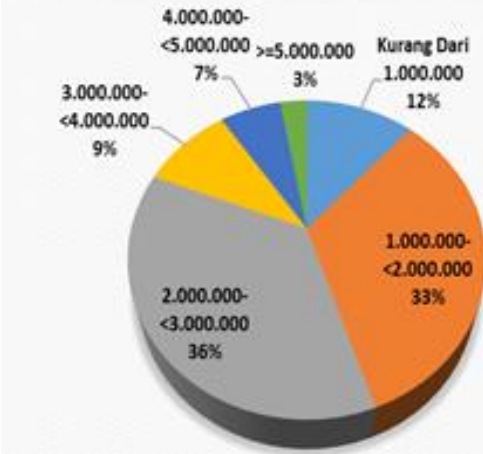

Gambar 6. Pendapatan alumni PTI sekarang

Banyaknya perusahaan yang telah dilamar oleh alumni untuk mendapatkan pekerjaan pertama masih tergolong sedikit, dilihat dari keahlian yang dimiliki oleh alumni. Dari 136 responden alumni PTI yang memberikan jawaban, hanya $9 \%$ alumni yang melamar pekerjaan lebih dari 5 perusahaan. Sebanyak $1 \%$ lebih dari 10 perusahaan dan sebanyak $90 \%$ kurang dari 5 perusahaan. Dan banyak perusahaan/Instansi/lembaga yang pernah alumni tempati untuk bekerja hanya $2 \%$ yang lebih dari 5 tempat bekerja, 98\% di bawah dari 5 tempat bekerja.

Adapun permasalahan yang dihadapi alumni PTI dalam mencari pekerjaan yaitu.

a. Persaingan tenaga kerja IT yang sangat ketat

b. Kompetisi

c. Masalah koneksi

d. Pengalaman kerja yang kurang

e. Kurangnya informasi lowongan pekerjaan

f. Sulit mencari sekolah yang masih menerapkan pembelajaran TIK akibat perubahan kurikulum menjadi kurikulum 2013

g. Keberanian dalam mencoba

h. Umur dan status sudah menikah

i. Jarak tempat kerja dengan rumah

j. Adaptasi dengan lingkungan

k. Mempelajari hal baru dalam tempat kerja

I. Modal usaha

$m$. Terbatasnya sekolah yang membutuhkan tenaga honorer

n. Kemampuan bahasa asing yang kurang terutama bahasa Inggris 
o. Susah mencari pekerjaan yang sesuai dengan keinginan

p. Mata kuliah di kampus kurang sesuai dengan kurikulum di SMK

q. Ketiak sesuaian antara bal yang diperoleh selama kuliah dengan jenis pekerjaan yang banyak tersedia di lapangan

r. Akreditasi Jurusan yang masih $\mathrm{C}$

s. Kurangnya sertifikat yang menunjukkan keterampilan

t. Kurangnya pengetahuan terhadap jaringan

\section{b. Keterserapan Capaian Pembelajaran Alumni PTI}

Keterserapan capaian pembelajaran alumni PTI dapat dilihat dari nilai IPK, penekanan aspek-aspek pembelajaran, penilaian alumni terhadap aspek belajar mengajar, penilaian alumni terhadap kondisi fasilitas belajar di Jurusan PTI, penilaian terhadap pengalaman belajar, dan penguasaan kompetensi alumni PTI.
Rata-rata nilai IPK alumni PTI sudah bagus yaitu dengan nilai IPK 3,1 3,5 sebanyak $76 \%$, untuk hasil persentasenya dapat dilihat pada Gambar 7.

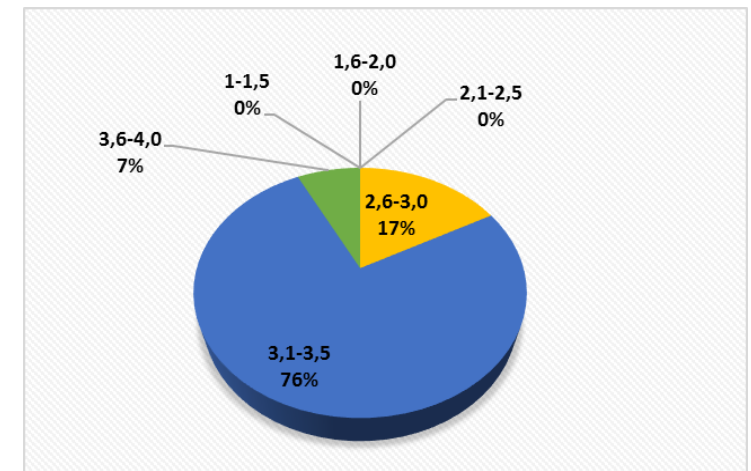

Gambar 7. Nilai IPK alumni PTI

Untuk penekanan aspek-aspek pembelajaran menurut alumni sudah berjalan dengan baik. Ini dapat dilihat pada Tabel 1.

Tabel 1. Penekanan aspek-aspek pembelajaran

\begin{tabular}{lrrrrrr}
\hline Pernyataan & $\begin{array}{c}\text { Sangat } \\
\text { kurang }\end{array}$ & Kurang & $\begin{array}{c}\text { Skala } \\
\text { Cukup }\end{array}$ & Baik & $\begin{array}{r}\text { Sangat } \\
\text { Baik }\end{array}$ & Max \\
\hline $\mathbf{1}$ & 0 & 1.37 & 8.9 & 72.6 & 17.12 & 72.60 \\
$\mathbf{2}$ & 0.68 & 3.42 & 25.34 & 66.44 & 4.11 & 66.44 \\
$\mathbf{3}$ & 6.85 & 12.33 & 47.95 & 28.08 & 4.79 & 47.95 \\
$\mathbf{4}$ & 0.68 & 2.74 & 15.75 & 65.75 & 15.07 & 65.75 \\
$\mathbf{5}$ & 0 & 0.68 & 23.29 & 65.75 & 10.27 & 65.75 \\
$\mathbf{6}$ & 0 & 1.37 & 22.6 & 62.33 & 13.7 & 62.33 \\
$\mathbf{7}$ & 5.48 & 17.12 & 38.36 & 32.88 & 6.16 & 38.36 \\
$\mathbf{8}$ & 0.68 & 3.42 & 25.34 & 66.44 & 4.11 & 66.44 \\
\hline
\end{tabular}

Untuk meningkatkan kualitas pembelajaran di Jurusan PTI perlu adanya penilaian dari alumni PTI tentang penilaian pengalaman belajar selama kuliah di Jurusan PTI. Adapun aspek yang dinilai yaitu bagaimana kualitas pembelajaran, suasana akademik, magang, pengabdian dan penjangkauan masyarakat, pelaksanaan riset/penulisan skripsi, organisasi kemahasiswaan, kegiatan ekstrakulikuler, rekreasi dan olahraga. Secara umum penilaian alumni PTI terhadap pengalaman belajar di Jurusan PTI dinilai sangat baik. Hasil persentasenya dapat dilihat pada Tabel 2.
Kegiatan perkuliahan tidak terbatas pada kegiatan belajar mengajar di dalam ruangan saja. Interaksi dengan dosen, diskusi kelompok, proyek riset dan saring pengalaman adalah kegiatan-kegiatan lain yang dapat dilakukan dan menunjang dalam perkuliahan. Tingkat aspek belajar mengajar bagi alumni PTI sudah dinilai baik. Yang termasuk ke dalam aspek belajar mengajar yang dinilai di sini yaitu kesempatan berinteraksi dengan dosen, kompetensi dosen, pembimbing akademik, kondisi umum belajar mengajar. Meskipun semua alumni sudah menilai baik namun masih perlu ditingkatkan lagi demi 
Tabel 2. Penilaian Alumni terhadap proses Pembelajaran.

\begin{tabular}{crrrrrr}
\hline Pernyataan & $\begin{array}{r}\text { Sangat } \\
\text { Kurang }\end{array}$ & Kurang & Cukup & Baik & $\begin{array}{r}\text { Sangat } \\
\text { Baik }\end{array}$ & Max \\
\hline 1 & 0.68 & 0 & 0 & 13.01 & 78.77 & 78.77 \\
2 & 1.37 & 0 & 0 & 13.01 & 78.77 & 78.77 \\
3 & 2.05 & 0.68 & 0.68 & 17.81 & 64.38 & 64.38 \\
4 & 2.74 & 0 & 2.05 & 26.71 & 60.96 & 60.96 \\
5 & 3.42 & 0 & 0.68 & 9.59 & 75.34 & 75.34 \\
6 & 4.11 & 0 & 2.05 & 17.12 & 71.23 & 71.23 \\
7 & 4.79 & 0 & 4.79 & 28.08 & 60.96 & 60.96 \\
8 & 5.48 & 0 & 14.38 & 55.48 & 29.45 & 55.48 \\
\hline
\end{tabular}

Tabel 3. Hasil persentase penilaian alumni terhadap aspek belajar mengajar.

\begin{tabular}{crrrrrr}
\hline Pernyataan & $\begin{array}{c}\text { Sangat } \\
\text { Kurang }\end{array}$ & Kurang & $\begin{array}{c}\text { Skala } \\
\text { Cukup }\end{array}$ & Baik & $\begin{array}{r}\text { Sangat } \\
\text { Baik }\end{array}$ & Max \\
\hline 1 & 0.68 & 0.68 & 17.12 & 66.44 & 15.07 & 66.44 \\
2 & 0.00 & 0.00 & 8.90 & 65.07 & 26.03 & 65.07 \\
3 & 0.00 & 0.00 & 8.22 & 50.68 & 41.10 & 50.68 \\
4 & 0.00 & 0.00 & 15.07 & 76.71 & 8.22 & 76.71 \\
\hline
\end{tabular}

Beragam aktivitas dapat terjadi yang dilakukan di jurusan PTI, setiap aktivitas yang terjadi dapat berjalan dengan optimal seiring baik tidaknya fasilitas yang menunjang. Fasilitas yang baik memberikan kesempatan bagi yang menjalankan kegiatan untuk memberikan hal terbaik dalam menjalaninya. Sementara fasilitas yang tidak memadai menjadikan kegiatan itu sendiri berjalan hanya apa adanya. Bagi alumni PTI, fasilitas di Jurusan PTI pada umumnya sudah memadai. Ini tampak dari sisi penilaian yang mereka berikan oleh alumni PTI, dimana yang paling tinggi nilainya yaitu pada perkembangan teknologi informasi dan komunikasi $67 \%$ dari 146 responden yang memberikan jawaban. Kemudian untuk perpustakaan, modul ajar, ruang belajar, laboratorium, variasi mata kuliah teori yang ditawarkan, variasi mata kuliah praktek yang ditawarkan, akomodasi, kantin, pusat kegiatan mahasiswa dan fasilitasnya, dan fasilitas kesehatan semuanya itu dinilai baik oleh alumni namun masih perlu di tingkatkan lagi. Ini menunjukkan kondisi fasilitas belajar di Jurusan PTI masih memadai, namun harus terus melakukan perbaikan demi kenyamanan perkuliahan di Jurusan PTI. Untuk hasil persentasenya dapat dilihat pada Tabel 4.

Tabel 4. Hasil persentase penilaain alumni terhadaf fasilitas di Jurusan PTI

\begin{tabular}{crrrrrr}
\hline Pernyataan & $\begin{array}{c}\text { Sangat } \\
\text { Kurang }\end{array}$ & Kurang & $\begin{array}{c}\text { Skala } \\
\text { Cukup }\end{array}$ & Baik & $\begin{array}{r}\text { Sangat } \\
\text { Baik }\end{array}$ & Max \\
\hline 1 & 2.05 & 6.85 & 21.92 & 60.96 & 8.22 & 60.96 \\
2 & 0.00 & 2.05 & 17.12 & 69.86 & 10.96 & 69.86 \\
3 & 0.00 & 4.11 & 30.14 & 63.01 & 2.74 & 63.01 \\
4 & 0.00 & 5.48 & 23.29 & 67.81 & 3.42 & 67.81
\end{tabular}




\begin{tabular}{crrrrrr}
5 & 0.00 & 2.74 & 13.70 & 65.75 & 17.81 & 65.75 \\
6 & 0.00 & 0.68 & 25.34 & 65.75 & 8.22 & 65.75 \\
7 & 0.00 & 3.42 & 31.51 & 57.53 & 7.53 & 57.53 \\
8 & 3.42 & 0.00 & 34.25 & 58.90 & 3.42 & 58.90 \\
9 & 0.68 & 7.53 & 34.93 & 52.74 & 4.11 & 52.74 \\
10 & 0.68 & 9.59 & 27.40 & 58.90 & 3.42 & 58.90 \\
11 & 4.79 & 23.97 & 41.10 & 29.45 & 0.68 & 41.10 \\
12 & 11.11 & 11.11 & 33.33 & 33.33 & 11.11 & 33.33 \\
\hline
\end{tabular}

Dalam sebuah lembaga tidak terlepas dengan adanya organisasi, dengan demikian selama alumni kuliah di Jurusan PTI sebanyak $74 \%$ alumni yang ikut dalam organisasi, baik itu organisasi di lingkungan kampus maupun organisasi di luar kampus. Bagi alumni PTI yang ikut dalam organisasi, ternyata tingkat keaktifan mereka dalam organisasi saat besar. Tingkat keaktifan ini berlaku di setiap himpunan/kegiatan yang mereka jalani selama di Jurusan PTI. Ini dapat dilihat dari hasil rata-rata persentase keaktifan alumni PTI dalam organisasi tersebut. Dari 74\% alumni PTI yang ikut organisasi, untuk alumni PTI yang Sangat aktif dalam organisasi yaitu sebanyak $17 \%$, aktif sebanyak $38 \%$, cukup aktif sebanyak $42 \%$, kurang aktif sebanyak $3 \%$. Kondisi ini memberikan gambaran pula bahwa alumni PTI tidak hanya baik dari segi prestasi keilmuan namun dalam kegiatan berorganisasi pula. Hasil persentasenya dapat dilihat pada Gambar 10 dan Gambar 11.

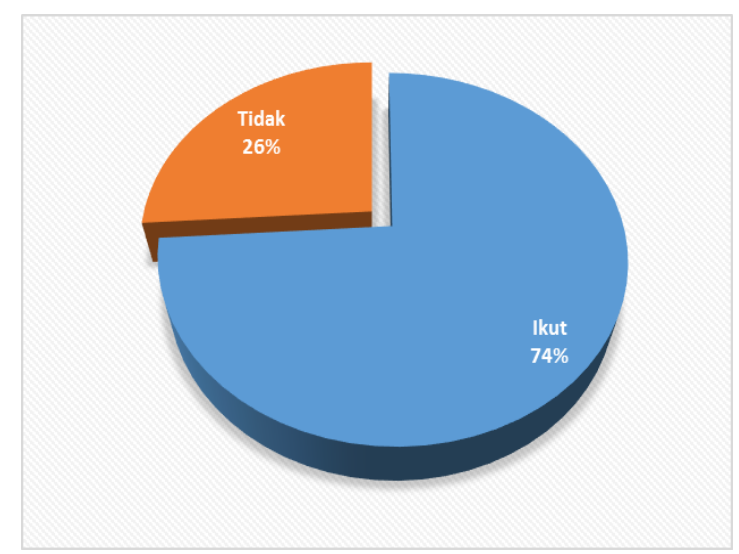

Gambar 10. Alumni PTI yang ikut Organisasi

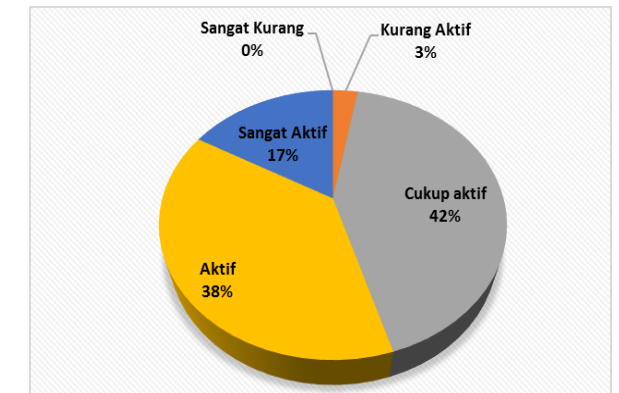

Gambar 11. Keaktifan alumni dalam organisasi yang diikutinya

Banyaknya alumni yang mengikuti kursus dapat dilihat pada Gambar 12. Dan jenis kursus yang diikuti alumni PTI dapat dilihat pada Gambar 13.

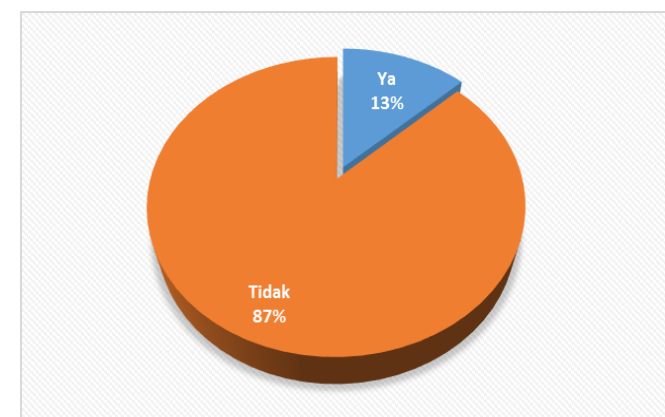

Gambar 12. Banyaknya alumni yang mengikuti kursus

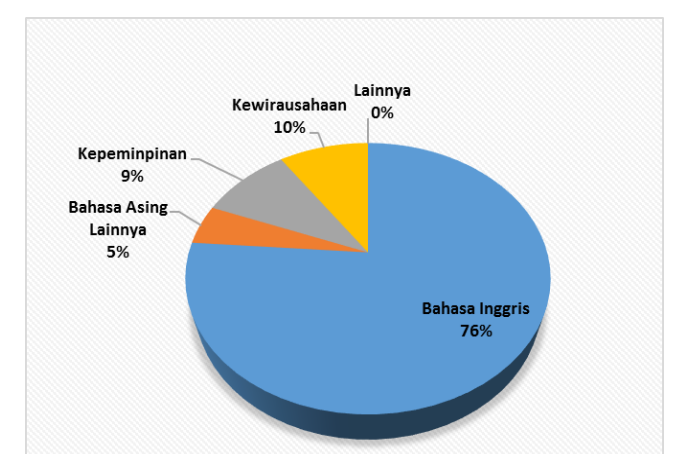

Gambar 13. Jenis Kursus yang diikuti alumni PTI

Kemampuan/kompetensi alumni PTI untuk memulai pekerjaan sebagian besar 
mereka dapatkan saat masih di perkuliahan. Beberapa kemampuan diperoleh dari perkuliahan itu sendiri dan sebagian lainnya dari melakukan kerja saat kuliah ataupun dasar dari kemampuan mereka. Kemampuan/ kompetensi alumni yang diperoleh dari perkuliahan utamanya akan sangat di dominasi pada pengetahuan di bidangnya. Namun alangkah baiknya jika kemampuan/kompetensi alumni tidak bergantung pada pengetahuan di bidang ilmu saja mengingat potensi dari setiap individu bermacam-macam. Membentuk lulusan yang disesuaikan dengan kebutuhan pasar kerja, dalam kaitannya dengan dunia industri/kerja, akan lebih baik lagi. Sesuai dengan kurikulum yang berkembang sekarang yaitu kurikulum KKNI di mana pada kurikulum ini yang paling utama tujuannya yaitu menciptakan lulusan agar sesuai dengan kebutuhan pasar kerja. Memberikan disiplin ilmu baik melalui proyek ilmiah, training, kuliah kerja nyata, riset ataupun partnership dengan perusahaan akan semakin menambah bobot kompetensi lulusan. Semakin baik bobot kompetensi yang dimiliki lulus suatu Jurusan maka diharapkan akan memberikan dampak positif terhadap dunia industri/kerja baik langsung ataupun tidak langsung. Secara umum gambaran mengenai kompetensi alumni PTI sudah pada kategori baik. Berapa hal yang menjadi penguasaan kompetensi yang dinilai lebih baik dari kompetensi lainnya yaitu pada kemampuan berkomunikasi, bekerja secara mandiri, bekerja dalam tim/bekerja dengan orang lain, kemampuan dalam memecahkan masalah, toleransi, kemampuan adaptasi, loyalitas dan integrasi, bekerja dengan orang yang berbeda budaya maupun latar belakang, dan kemampuan dalam memegang tanggung jawab. Sementara yang lainnya sudah dinilai baik namun masih perlu ditingkatkan lagi yaitu pada bidang ilmu kemampuan riset dan keterampilan riset.

Pembekalan kompetensi alumni PTI sebagian besar diperoleh saat berada di Jurusan. Namun, tidak semua kemampuan ini didapat dari hasil perkuliahan di Jurusan saja. Beberapa kemampuan sangat memungkinkan diperoleh alumni dengan mengambil kursus tambahan, baik yang difasilitasi oleh Jurusan atau bahkan dengan mengambil kursus di luar. Alumni PTI yang mengambil kursus saat menjalani perkuliahan maupun setelah kuliah ada sebanyak 19 orang (13\%) dari total alumni yang memberikan respons yaitu sebanyak 146 orang. Sebagian besar kursus yang diambil yaitu kursus bahasa Inggris sebanyak $76 \%$. Pengambilan kursus tersebut sangat berperan pada saat mendapatkan pekerjaan yang memuaskan/sesuai harapan dan pada saat memulai pekerjaan. Sebanyak $74 \%$ alumni PTI menyatakan perlunya untuk meningkatkan kompetisinya dengan mengambil kursus lagi. Ini menunjukkan bahwa untuk penguasaan bahasa asing pada alumni PTI masih kurang sehingga untuk mata pelajaran bahasa asing khususnya bahasa Inggris di jurusan perlu di perdalam lagi.

\section{c. Umpan balik Alumni PTI dan Pengguna Alumni PTI}

Kehidupan bekerja bagi alumni PTI tidak akan terlepas dari kehidupan saat masih menjadi mahasiswa di Jurusan PTI. Tidak sedikit alumni PTI yang bekerja ataupun berwirausaha disesuaikan dengan kemampuan yang mereka miliki selama mereka menjalani kehidupan perkuliahan di PTI. Kesesuaian kuliah dengan pekerjaan memang menjadi dasar yang cukup berarti bagi alumni dalam menjalani kehidupan kerja. Dengan terciptanya kesesuaian, dari sisi alumni hal tersebut akan sangat membantu terkait berkembang tidaknya ilmu yang mereka miliki. Di sisi lain, bagi jurusan kesesuaian kuliah akan berdampak pada ketepatan program studi yang mereka jalankan setiap kurikulumnya. Kesesuaian kuliah dengan pekerjaan bagi alumni PTI cukup besar, yaitu sebanyak $74 \%$. Hal ini menggambarkan bahwa mayoritas alumni PTI yang bekerja dan berusaha menjalani pekerjaan mereka sesuai dengan kapabilitas mereka yang sebenarnya. Bagi alumni yang menyatakan pekerjaannya tidak sesuai dengan bidang pendidikannya sebayak $26 \%$. Mereka harus mengambil 
pekerjaan tersebut kebanyakan karena pada pekerjaan tersebut mereka mendapatkan prospek yang lebih baik dan belum mendapatkan pekerjaan yang sesuai dengan pendidikannya. Hasil persentasenya dapat dilihat pada Gambar 14 dan Gambar 15.

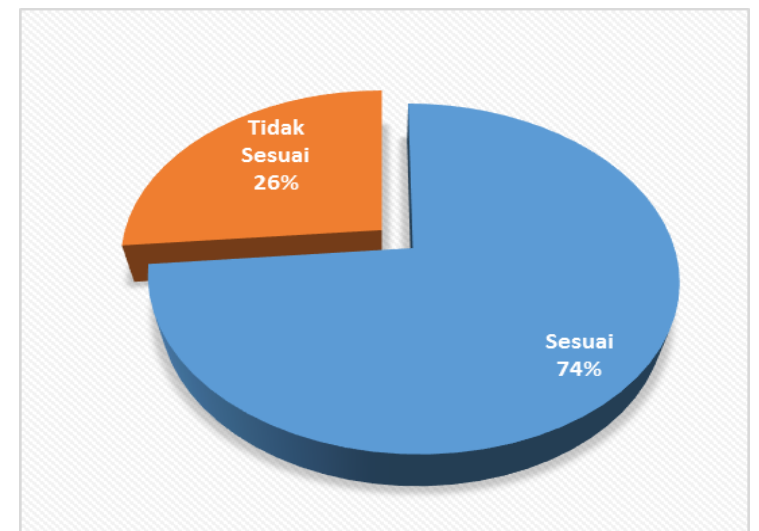

Gambar 14. Kesesuaian bidang pendidikan dengan bidang pekerjaan alumni PTI

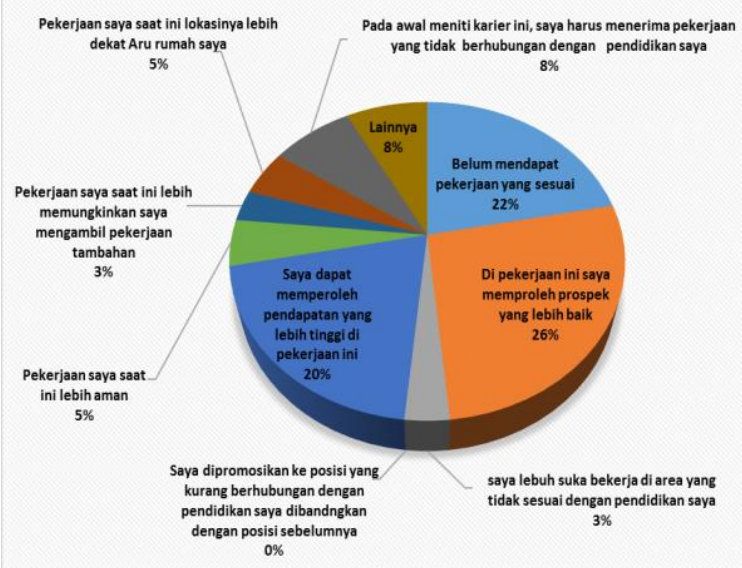

Gambar 15. Alasan Alumni PTI mengambil pekerjaan pertama

Pekerjaan merupakan kebutuhan bagi semua alumni PTI yang telah lulus. Kebutuhan akan pekerjaan dapat didasarkan pada beberapa hal, di antaranya gaji, kedekatan dengan rumah, tantangan pekerjaan, benefit, dan kesempatan beasiswa. Bagi alumni aspek yang menjadi pertimbangan dalam memilih pekerjaan sebagian besar pada gajinya yaitu sebanyak $42 \%$, tantangan pekerjaan sebanyak $19 \%$, kedekatan dengan rumah sebanyak $16 \%$, benefit sebanyak $11 \%$, dan kesempatan beasiswa sebanyak 4\%. Kondisi ini menunjukkan bahwa alumni PTI lebih mementingkan pendapatan. Hasil persentasenya dapat dilihat pada Gambar 16.

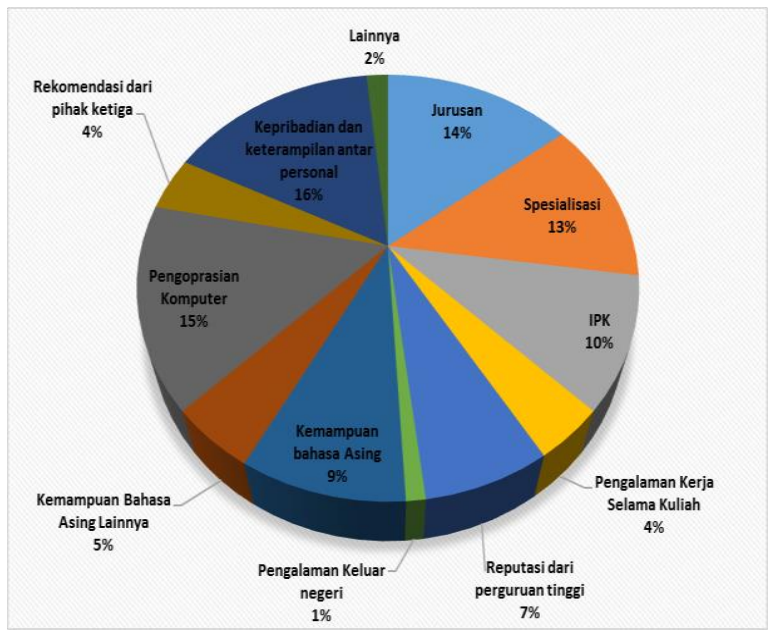

Gambar 16. Aspek yang menjadi pertimbangan dalam mencari kerja

Peranan Jurusan PTI bagi alumni PTI dalam dunia kerja sebagian besar sudah baik dan yang masih kurang yaitu dalam hal terkait dengan pengembangan diri. Untuk peran kompetensi yang di peroleh di Jurusan PTI menurut alumni sudah berperan namun masih perlu ditingkatkan lagi. Untuk kebermanfaatan prakerin, KKN dan PPL-Real sudah sangat bermanfaat karena dengan kegiatan tersebut alumni bisa mendapatkan pengalaman bagaimana menjadi pendidik, bagaimana bekerja di tempat kerja yang sesungguhnya dan bagaimana bersosialisasi dengan masyarakat di sekitarnya. Untuk alumni yang bekerja di SMK ada beberapa materi yang belum maksimal di dapatkan di jurusan PTI yaitu khususnya dalam bidang TKJ dan Multimedia. Secara umum saran dari alumni terhadap jurusan PTI yaitu agar bisa menciptakan lulusan yang sesuai dengan kebutuhan di pasar kerja dan sesuaikan kurikulum di Jurusan PTI dengan kurikulum yang di terapkan di SMK.

Penilaian kinerja alumni merupakan gambaran lulusan jurusan PTI semakin baik tanggapan pengguna alumni PTI terhadap kinerja alumni semakin baik juga penilaian Pengguna alumni terhadap 
jurusan PTI. Menurut pengguna alumni secara umum untuk kinerja alumni PTI sudah dinilai baik. Untuk penggunaan teknologi informasi sudah sangat baik, kemudian untuk keluasan wawasan antar disiplin ilmu, kepemimpinan, dan komunikasi sudah dinilai baik oleh pengguna alumni.

Hal yang masih kurang dari alumni PTI yaitu kemampuan bahasa asing. Bidang yang kurang dikuasai oleh alumni PTI yaitu sebagian besar dalam bidang komunikasi dan prestasi terutama penggunaan bahasa Inggris sebanyak $31 \%$ dan Kepemimpinan sebanyak $28 \%$. Hasil persentasenya dapat dilihat pada Gambar 17.

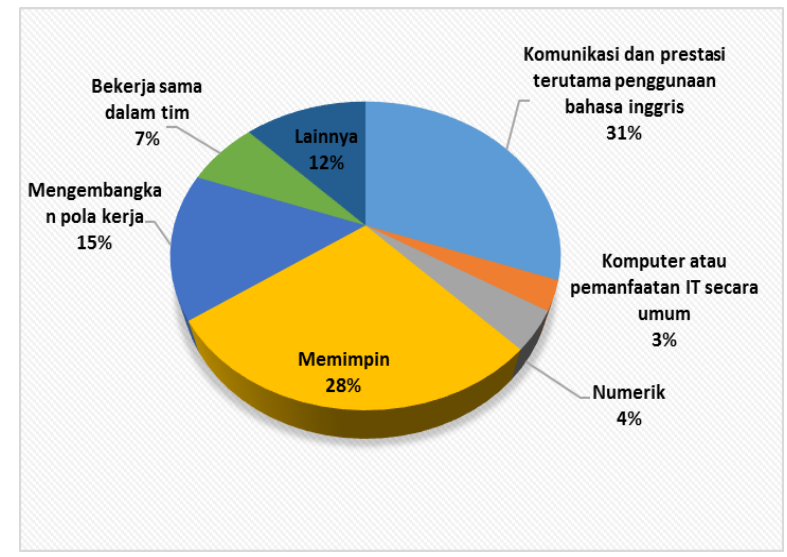

Gambar 17. Hasil persentase kererampilan yang kurang dikuasai Alumni PTI

Dari 73 responden pengguna alumni yang menyatakan perlunya keterampilan tambahan sebanyak $64,4 \%$ dan menyatakan tidak perlu sebanyak $35,6 \%$. Kemudian dari 73 responden yang memberikan saran sebanyak $67,1 \%$ dan yang tidak memberikan saran sebanyak $31,9 \%$.

Umpan balik bagi pengguna alumni yaitu Secara umum tanggapan pengguna alumni PTI terhadap kinerjanya sudah di nilai baik namun ada beberapa yang masih kurang yaitu dalam bidang komunikasi dan prestasi terutama penggunaan bahasa Inggris dan Kepemimpinan. Sehingga ada beberapa keterampilan tambahan yang harus di dapatkan dari jurusan PTI yaitu Keterampilan berbahasa asing khususnya bahasa Inggris, praktek jaringan TCP/IP, bidang bisnis, manajemen keuangan dan promosi, desain komunikasi visual, ilmu kesehatan, pengolahan data perkantoran, soft skill, pendidikan karakter, kreativitas dan inovasi dalam pengolahan sampah/ limbah, kepemimpinan, pengembangan aplikasi dan hal-hal yang berkaitan dengan data sekolah, pemanfaatan software untuk pengembangan pola bisnis, animasi 2 dimensi, animasi dan video editing, meningkatkan kreativitas dalam bidang marketing, desain dan kompetensi produk, IImu progreming dan animasi, keterampilan multimedia khususnya perfileman, manajemen waktu.

\section{SIMPULAN DAN SARAN}

Profil alumni PTI mempunyai masa tunggu lulusan sebagian besar kurang dari enam bulan, sebagian alumni sudah bekerja sesuai dengan latar belakang pendidikannya, dalam bidang peneliti dan pengembang sistem teknologi Informatika sebanyak $4 \%$, dalam bidang pendidik informatika sebanyak $45 \%$, dalam bidang wirausaha bidang TIK sebanyak 53\%, kemudian dalam bidang peneliti belum ada. Besar penghasilan pertama yang diperoleh lulusan sebesar 1-2 juta rupiah. Atas dasar kondisi profil alumni PTI tersebut bahwa lulusan yang di hasilkan Jurusan PTI sudah sesuai dengan profil lulusan Jurusan PTI.

Capaian pembelajaran alumni PTI silikat dari nilai IPK yang di peroleh alumni PTI sebagian besar 3,1 - 3,5 sebanyak $76 \%$. Kemudian dalam hal penekanan aspek-aspek pembelajaran sudah berjalan dengan bagus namun perlu ditingkatkan lagi terutama dalam partisipasi dalam proyek riset dosen dan kesempatan ikut menentukan kebijakan yang berdampak terhadap kebijakan jurusan. Untuk aspek belajar mengajar, kondisi fasilitas belajar di Jurusan PTI, pengalaman belajar, dan penguasaan kompetensi alumni PTI sudah baik namun masih perlu ditingkatkan lagi sehingga lulusan Jurusan PTI. 


\section{DAFTAR PUSTAKA}

Bungin, B. 2009. Metodologi Penelitian Kuantitatif : Komunikasi, Ekonomi dan Kebijakan Publik serta IImu-IImu Sosial Lainnya. Jakarta.

Candiasa, I Made.2010. Pengujian Instrumen Penelitian disertai Aplikasi Iteman dan Bigsteps. Singaraja:Unit Penerbitan Universitas Pendidikan Ganesha.

K-DIKTI. 2014. Buku Kurikulum Pendidikan Tinggi. Jakarta: Direktorat Pembelajaran dan Kemahasiswaan.

ITB. 2014. Report Tracer Study tahun 2014. ITB CareerCenter: Lembaga Kemahasiswaan.

Rasiman, Adi, Joko, Nurhadi. 2008. Penelusuran Lulusan Program Studi Pendidikan Matematika IKIP PGRI Semarang Melalui Studi Pelacakan (Tracer Study) Sebagai Umpan Balik Penyempurnaan Kurikulum Tahun 2008. Jurnal Media Penelitian Pendidikan, Volume 2 Nomor 2 Desember 2008.

Schomburg, Harald. 2003. Handout for Graduate Tracer Studies. International Centre for Higher Education Research (INCHERKassel) University Kassel. Germany.

Sudirta. 2013. Profil alumni fakultas teknik dan kejuruan Universitas Pendidikan Ganesha ditinjau dari keterserapannya di dunia kerja. ISSN 0216-3241. 